\title{
There is no one amongst us with them! Transparency and participation in local natural resource revenue management
}

\author{
Sam A. Kasimba ${ }^{1}$ and Päivi Lujala ${ }^{2}$ \\ ${ }^{1}$ Department of Geography, Norwegian University of Science and Technology (NTNU), 7491 \\ Trondheim, Norway. Email: sam.kasimba@ntnu.no \\ 2 Department of Geography, Geography Research Unit, PL 8000, 90014 University of Oulu, \\ Finland. Email: paivi.lujala@oulu.fi \& Norwegian University of Science and Technology \\ (NTNU), 7491 Trondheim, Norway
}

\begin{abstract}
To redistribute natural resource revenues back to local communities and to promote equitable benefit-sharing and inclusive decision-making, companies and governments increasingly use local benefit-sharing trust funds (LBSTFs) in resource-rich developing countries. Many LBSTFs manage substantial amounts of money, often in regions far from the central government and amongst politically and economically marginalized groups. Focusing on two LBSTFs in Ghana, this article examines the challenges for meaningful participation by local residents. The findings indicate that local residents lack access to relevant information, that the representation mechanisms in place restrict their opportunities to voice their opinions, and that they have no real influence on decision-making. In general, local residents feel a low sense of ownership towards the funds and the funded projects. The results suggest that to enhance meaningful participation, an LBSTF should be independent from the mining company and the intended beneficiaries themselves should be able to choose their representatives for the fund.
\end{abstract}

\section{Keywords}

Ghana; local natural resource governance; transparency; accountability; participation

\section{Funding}

This work was supported by the Research Council of Norway [Grant No. 231757] and the Academy of Finland [Grant Nos. 314143 and 309206]. 


\section{Introduction}

For host communities, the extraction of valuable natural resources poses a wide range of challenges related to environmental, social, and economic issues. To redistribute revenues back to these areas, to target revenues to the local communities most affected by extraction activities, and to target local needs, companies and governments increasingly use local benefit-sharing trust funds (LBSTFs) as the means to manage natural resource revenues and, in some cases, to circumvent different governmental levels and agencies (Dupuy, 2017; Maconachie, 2012; Songi, 2015; Wall \& Pelon, 2010, 2011). ${ }^{1}$ Many LBSTFs manage substantial amounts of money. For example, the Newmont Ahafo Development Foundation (NADeF) in Ghana received approximately US\$ 35 million between 2008 and 2017 from Newmont Ahafo Mines, and the Ok Tedi Development Foundation in Papua New Guinea, funded by Rio Tinto, had an annual expenditure of US\$ 6.7 million in 2017 (NADeF, 2016, 2018; OTDF, 2018; Wall \& Pelon, 2011). ${ }^{2}$

One of the key arguments for LBSTFs is that they can better ensure local community members' participation in local natural resource revenue management (IFC, 2015). Participation is seen as

${ }^{1}$ These types of institutions are commonly referred to as funds, foundations, trusts, or community development funds. They are most prevalent in the extractive sector, and rapidly increased in number during the 1990s and 2000s (Wall \& Pelon, 2010). LBSTFs are established for different reasons and by different actors, and have different structures and legal forms, but they commonly seek to promote long-term development, improved living conditions, or/and equitable revenue sharing in the communities affected by extraction through development projects that promote education, health, infrastructure, job creation, and small-scale businesses and that are initiated and implemented in cooperation with local community members (Wall \& Pelon, 2010). In this article, we refer to these institutions as local benefit-sharing trust funds (LBSTFs) or just "funds" or "trust funds".

${ }^{2}$ LBSTFs are part of the process of decentralizing natural resource revenue management from the central government to subnational governmental and other local actors. The most common forms through which revenues are returned to extraction areas are the different fiscal decentralization mechanisms. These mechanisms, however, are commonly criticized as being beyond the local government's capacity to manage the (often volatile) revenue flows and to adequately plan for spending, and can potentially feed into corruption and patronage networks when the accountability mechanisms in place are weak or lacking (IFC, 2015; Ross, Lujala, \& Rustad, 2012). 
key to equitable benefit-sharing and inclusive decision-making, which in turn are likely to lead to activities that better address the needs of the community and promote sustainable development, and greater sense of ownership (Fabricius, 2013; Gebara, 2013).

In this article, we develop an analytical framework to examine the local community members' space for participation in LBSTF management. The framework incorporates (i) transparency in the trust fund's operations, (ii) representation of local residents in the trust fund's decision-making bodies, and (iii) local residents' opportunity to exert real influence on the management of the fund by enabling conditions for meaningful participation through local community members in trust fund management. By focusing on two LBSTFs in Ghana - the Obuasi Community Trust Fund (Obuasi Fund) and the NADeF - we use the framework to examine the scope and challenges the local community members have in engaging in LBSTF management and revenue use. In particular, we focus on whether relevant information on the trust fund management and operation is available to the community members, whether community members are genuinely represented in the decision-making bodies, and whether they have a real opportunity to influence the trust fund management and operation.

The analysis of the two case LBSTFs provides four key findings. First, despite the efforts by the studied trust funds to make information on trust funds and their operations available, the local residents unequivocally stated that communication from the trust funds was scarce and the disclosed information tended to be insufficient, irrelevant, and difficult to understand. The lack of (relevant) information limited the residents' basis to voice concerns about fund management, as they had an insufficient knowledge base to form qualified opinions about the funds and their management. The lack of information also evoked general distrust towards the funds. Second, the trust funds employ forms of community representation that overwhelmingly include persons already holding a position of power or influence in the community, such as chiefs or politicians. 
This practice seriously weakens the opportunities for direct participation in decision-making by ordinary community members. Third, due to the lack of relevant information and opportunities to voice concerns, the community members were extremely dissatisfied with their opportunities to influence fund management, which, in turn, demotivated them to search for more information about the trust funds and their operations. Consequently, the community members deemed the funds to be neither transparent nor accountable and felt little ownership towards the funds. Fourth, the transparency and representation mechanisms in place not only have restricted community members' space for participation in trust fund management but also to an extent seem to have strengthened the existing power relations and social and political patronage networks in the study areas.

This article makes five contributions to the existing literature. First, it adds to the limited academic research conducted on LBSTFs. To our knowledge, the only exceptions are the Diamond Community Area Development Fund (DACDF) in Sierra Leone (Maconachie, 2012) and the Ok Tedi Development Foundation in Papua New Guinea (Campbell, 2011; Gilberthorpe, 2013). There thus exists surprisingly little research on such funds especially when taking into account their potential to promote local development and their increasing popularity as tools to distribute benefits to mining communities (Songi, 2015; Wall \& Pelon, 2011). Second, by focusing on LBSTFs, this article expands our knowledge on the redistribution and sharing of benefits from the extractive industry at the local level that so far has mostly focused on company-community relations, corporate social responsibility, and local content policies (Andrews, 2016; Hilson, 2012; Kolk, 2016; Ovadia, 2016). Third, this article offers an analytical approach for studying meaningful participation through three enabling conditions: access to relevant information, representation in decision-making bodies, and having real opportunity to influence the decisions made. It thus provides a complementary approach to study and understand how citizens' space for participation 
can be enlarged and restricted (Eversole, 2010; Gebara, 2013; O'Faircheallaigh, 2010; O'Faircheallaigh \& Corbett, 2005; Perreault, 2015). Fourth, this study contributes to the emerging literature on the decentralization of revenue distribution and how sub-national structures and institutions can contribute to natural resource curse (Arellano-Yanguas, 2011; Gilberthorpe \& Papyrakis, 2015; Lawer, Lukas, \& Jørgensen, 2017). Finally, this article underlines the need to clearly differentiate between information disclosure (i.e., nominal transparency) and substantive transparency (Heald, 2006; Ofori \& Lujala, 2015).

The rest of the article proceeds as follows. Section 2 presents the analytical framework and Section 3 the research context and the analysis material. The results are presented in Section 4 and Section 5 concludes with a discussion and some policy implications.

\section{Participation in local benefit-sharing trust fund management}

Ideally, decisions on the use of local revenues from natural resource extraction should reflect the will of the majority, not only those of the elite, professionals, or the company. In that regard, participation is often mentioned as a key ingredient in creating spaces for citizen influence, empowering the marginalized and amplifying their voices, and enhancing inclusive decisionmaking (Cornwall, 2006; Speer, 2012).

Several conditions must be in place if an LBSTF is to ensure meaningful participation ${ }^{3}$ in the management of LBSTFs by local residents. First, local residents must receive comprehensible, relevant, and timely information on the trust fund and its functions. Second, there must be spaces for local residents to voice their concerns and demands. Finally, there must be an opportunity for such actions to affect the decisions made in the trust funds. In other words, transparency, the

\footnotetext{
${ }^{3}$ Meaningful participation enables not only people to voice their opinions and concerns but also, importantly, enables them to exercise power.
} 
representation of local voices, and accountability (that is, the citizens voices' having on impact on the decisions made) form the necessary conditions for a space of meaningful participation to emerge (see Figure 1). These three aspects form the backbone of our analytical framework for studying transparency and participation in trust funds.

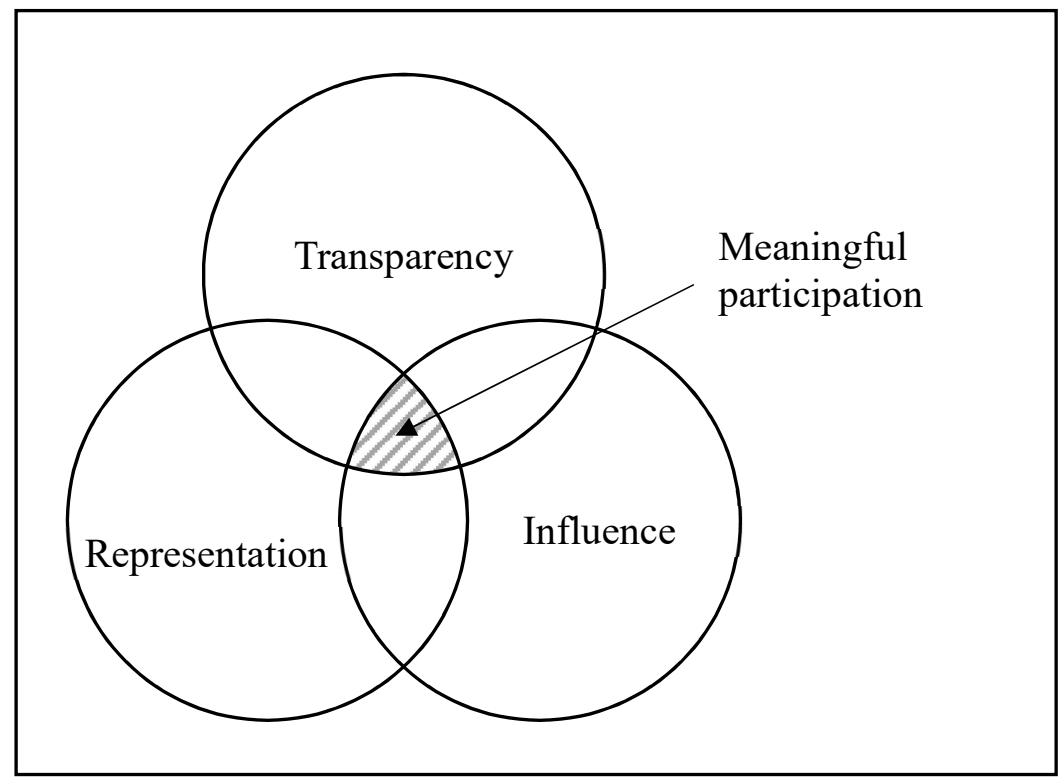

Figure 1. The conditions for meaningful participation

\subsection{Transparency}

Local residents need information on several aspects of the trust funds to enable them to observe what happens in the trust fund, to influence the revenue spending, and to evaluate the fund's performance. This information needs to not only be publicly available but also needs to be understandable, relevant, and accessible, enabling substantive adjustments in information asymmetry between the trust fund and local community members. This provides the potential for information to act as a basis to form or amend views on fund management by the community 
members, and, when desirable, to voice concerns and request changes in how the fund is being managed (Epremian, Lujala, \& Bruch, 2016; Heald, 2006).

In terms of public service production, information disclosure needs to encompass the fund's inputs, outputs, and the process linking these two aspects (Heald, 2006). In other words, local residents need information on the inputs that the trust fund receives: the amount of funding and, when relevant, the received assets (for example, cars or other equipment). These inputs form the basis for the expectations of what the fund can possibly achieve. Residents also need information on the outputs, for instance, the number of boreholes constructed or scholarships awarded, to judge the meaningfulness of revenue spending. Moreover, by matching the inputs and outputs, local community members can form opinions about whether the results are reasonable with regard to the allocations that the fund receives.

Further, local people need information about the processes that link the inputs to the outputs. What are the criteria used in the selection of the funded projects? Who proposed the specific project, what is the project design, and how is the implementation to proceed? Local people may also need information about specific aspects of the funded projects such as who owns the construction firm and what was the basis for its selection.

In many cases, the outputs are easily observable (e.g., a constructed health clinic or drilled boreholes), and the information on inputs should be relatively easy for the trust fund to disclose. A more demanding task for LBSTFs is to disclose information on the processes linking the inputs and outputs because providing information on the more day-to-day operations can be costly, especially on a continuous basis. However, within the trust fund context, achieving genuine participation requires openness about the processes that link the financial contributions that the fund receives to the concrete results to which it contributes, and that information should be available in (nearly) real time rather than retrospectively. 
For transparency to be transformative, that is, for it to have an effect on peoples' attitudes, beliefs, or actions, the disclosed information must be accessible and timely. For example, annual reports on funded projects and records for projects implemented several years ago are most likely to be of limited value for local residents, as these types of documentation do not provide a basis for present-day opinion making and handling. A further aspect is the physical accessibility of the information - the information must be available such that local residents can easily access it. The information must also be comprehensible so that residents can understand the content and utilize it appropriately.

\subsection{Representation}

As local residents are key stakeholders in LBSTFs, being the intended beneficiaries, their voices need representation in trust fund management. An underlying condition for this is the willingness of local community members to become involved in fund management, making local community members' sense of ownership an import aspect of representation.

The legitimacy of representatives and their capacity to articulate and promote the interests of the people whom they represent is crucial, as processes and procedures to select or appoint representatives may favour some individuals over others; the challenge is to ensure a legitimate voice for the affected communities (O'Faircheallaigh, 2013). In the context of LBSTFs, obscure representation can unfold when representation ensues from the existing social, political, or economic settings (Maconachie, 2012).

Furthermore, the control of trust funds may rest firmly in the hands of the mining company and existing elites if local residents' participation is constrained by the underlying power structures or if community leaders assume the representation of local residents. In these cases, the representation may lead to a situation where individuals represent the communities in the fund but lack a mandate 
from them. Such situations can lead to non-representative representation and can considerably limit the space and scope for participation in trust fund management by local residents.

\subsection{Influence}

The idea behind community participation is that local residents have better knowledge of their needs than do outsiders and are thus better placed to identify local problems (Bebbington, Leni, Erwin, \& Scott, 2006). Therefore, within the LBSTF context, it must be acknowledged that local residents poses knowledge and expertise about a community's existing resources, needs, and potentials that can be drawn on to influence and improve the management of the trust funds. For the trust funds, the implication is that the knowledge possessed by community members and their opinions, concerns, and demands should influence favourable management of the trust funds.

However, for real influence to take place, the trust fund must not only hear the voices of local residents but also be willing to act on them. Thus, the trust fund must be accountable to local residents in the sense that it modifies its functions according to the feedback and demands that it receives. The underlying argument here is that community members possess knowledge that is useful for the management of the fund and are in a better position to identify the most pressing needs in the community.

\section{Research context and material}

Together with petroleum, gold production comprises a lion's share of Ghana's merchandized exports; whilst approximately $12 \%$ comes from offshore petroleum exploitation, $40 \%$ comes from gold mining, which also places the country amongst the ten largest gold producers in the world (Ayensu, 2013; Bloch \& Owusu, 2012). Gold mining is prominent in the Western, Central, Eastern, Ashanti and Brong-Ahafo regions (see Figure 2). However, there is little evidence that the communities hosting industrial gold mining companies have benefited from doing so in socio- 
economic terms (Akabzaa, 2009; Elbra, 2017). Recent research points to corruption, elite capture, and the inadequate distribution of benefits as the main causes for the limited welfare increase in these communities (Dupuy, 2017; Standing, 2014).

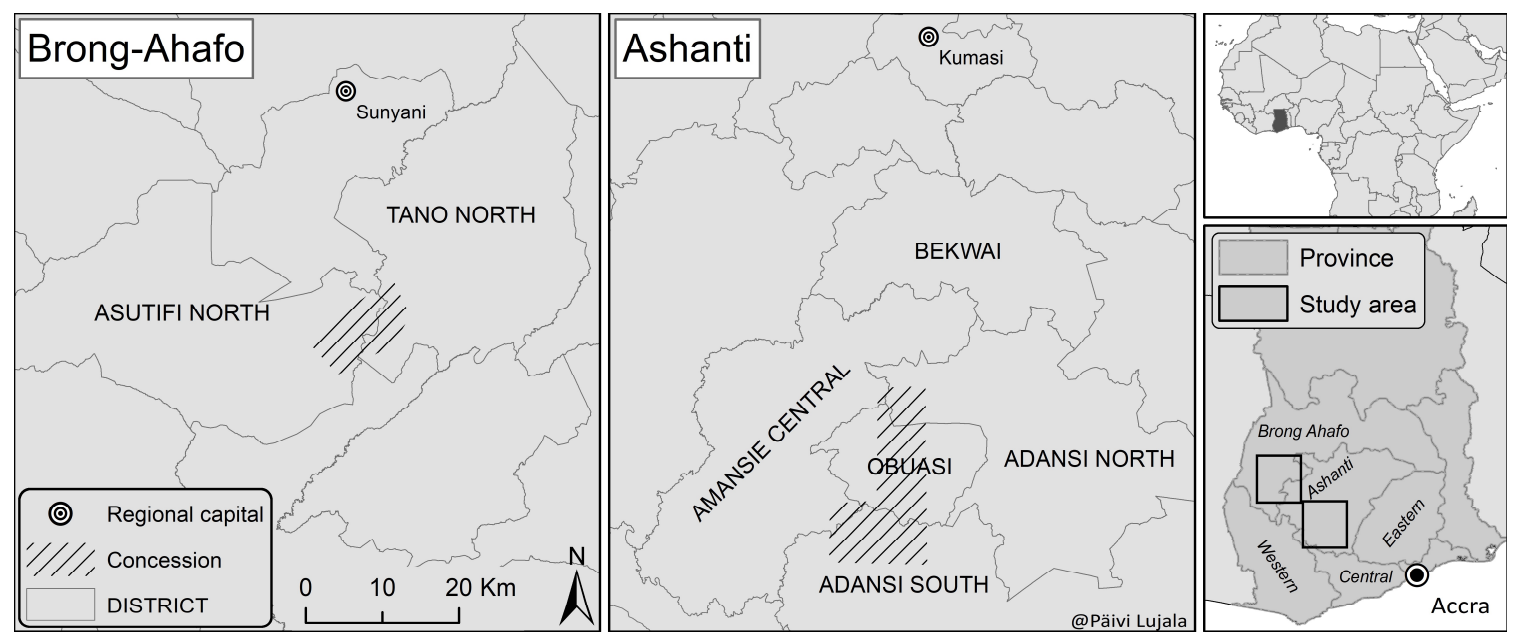

Figure 2. The study areas and approximate concession locations for Newmont in Ahafo and AGA in Obuasi.

The fieldwork was conducted in Ghana between October 2015 and April 2016 in the Adansi North District and the Obuasi Municipality in the Ashanti Region and in the Asufiti North and Tano North Districts in the Brong-Ahafo Region (see Figure 2). In total, 43 individual interviews (21 in Ashanti and 22 in Brong-Ahafo) and three group interviews (1 in Ashanti and 2 in BrongAhafo) were conducted.

A local journalist facilitated access to the first field contacts in both study areas (i.e., local NGOs), after which the snowballing technique led to interviews with local community members. Any adult (age $18+$ ) member of the community was considered a potential informant, and the interviews targeted community members with diverse social, political, religious, and economic 
backgrounds. Half of the community respondents were females. Interviews were also conducted with representatives from civil society organizations working in mining communities. These included the Wassa Association of Communities Affected by Mining (WACAM) in Tema (Greater Accra Region) and its sub-branch in Kenyasi 1 (Brong-Ahafo), and the Center for Social Impact Studies (CeSIS) in Obuasi. Purposive sampling was used to select trust fund representatives, a representative for the sustainability department of Anglo Gold Ashanti (AGA) in Obuasi, and local government officials with expertise in the trust funds' operations for interviews.

The interviews were semi-structured and held in English but facilitated by a translator (Twi) to ensure better comprehension of the questions and answers. The main themes covered in the interviews included the respondent's views and perceptions about information disclosure, representation, and influence with regard to the studied trust fund. The community member interviews also sought to understand the respondent's perceptions about the fund's governance structures, the extent to which the respondent felt ownership towards the trust fund, and his/her views on the implemented projects. The interviews were voice recorded and transcribed. The transcribed interviews were coded manually to identify the different actors' perceptions on (i) information disclosed by the trust funds in terms of content, accessibility, and relevance; (ii) representation mechanisms in the trust fund; and (iii) to what extent local residents are able to influence decision-making in the trust funds. After that, the identified material was screened for patterns and interpreted.

The secondary sources of analysis material consisted of the Obuasi Fund and NADeF's webpages, annual reports, and available guidelines for their operations. This material was used to examine how the trust funds disclose information, what information is being made available, and the representation mechanisms in place. 


\subsection{Obuasi Community Trust Fund}

The Obuasi town, which is the capital of the Obuasi Municipality, is located approximately $60 \mathrm{~km}$ from Kumasi (the capital of the Ashanti Region). Since 1897, Ashanti Goldfields Corporation, now AGA, has dominated the large-scale mining in Obuasi. Its concession covers over $20 \%$ of Obuasi Municipality's surface, and approximately 80 communities reside within or close to the concession. Gold from Obuasi accounts for over 50\% of Ghana's gold production, and most of the social and economic activities in the municipality relate to gold mining, creating a strong linkage between AGA and the residents (Akabzaa, Seyire, \& Afriyie, 2007; Asuah \& Ankoye, 2016). As one informant put it: 'Obuasi is AGA, and AGA is Obuasi'.

In 2004, AGA established the Obuasi Community Trust Fund (Obuasi Fund) to enhance socioeconomic development in the local communities. The company pledged $1 \%$ of its annual post-tax profits to the fund, and the trust fund accrued US\$ 2.7 million between 2004 and $2012 .{ }^{4}$ The intended beneficiaries of the fund include the people living in the Obuasi Municipality and the affected communities in the four surrounding districts (the Bekwai Municipality, the Amansie Central District, the Adansi North District, and the Adansi South District).

The fund comprises a board, a steering committee, and the secretariat. The board has seven members: two paramount chiefs from the Amansie and Adansi traditional areas (of which Obuasi is part), three district assembly members, one AGA representative (sustainability manager), and the board secretary, who is appointed by AGA. The board is responsible for overseeing the overall operations of the fund, makes decisions concerning how the funds are spent, and form policies

\footnotetext{
${ }^{4}$ No further information was available on the funding situation for the period after 2012, most likely because of the temporary closures of the mine and the uncertain future of the mine.
} 
guiding the secretariat. The board also ensures that the fund fulfils its mandate and operates according to guidelines.

The steering committee consists of 32 elected representatives including traditional authorities, municipal planning officers, women's group and youth group members, and representatives from local NGOs and other civil society groups. The committee serves as a meeting point for all stakeholders and, according to the secretariat, is the main platform for decision-making, from project selection to implementation. It is the key meeting point between the trust fund and the communities. However, all the decisions it makes need the board's approval.

The secretariat, employed by the board, is responsible for the running of the fund on a daily basis. It includes a project manager, an administrative officer who is also responsible for contracts, and two project officers. During the fieldwork, the project manager position was unoccupied, and AGA's sustainability manager had assumed responsibility for the position.

The Obuasi Fund finances community development projects and economic support to develop local businesses. In cooperation with AGA, the trust fund has donated equipment to the local hospital, built classrooms, offered scholarships, and constructed sports grounds. Most prominent has been the construction of public toilets and water boreholes in different communities. To develop local small-scale business, the fund finances capacity building and provides micro-credit loans.

Community members can apply for funds through their district assembly or unit committee members (the latter are representatives for village groups). The secretariat receives the funding applications and forwards them to the steering committee for assessment before sending them to the board for final approval.

\subsection{Newmont Ahafo Development Foundation}


In the Brong-Ahafo Region, large-scale mining began in the 1990s and is mostly concentrated in Ahafo, which is located $40 \mathrm{~km}$ south of Sunyani (capital of the Brong-Ahafo Region). Newmont's subsidiary, Newmont Ahafo Mine, has dominated industrial gold mining in the area since 2006, and its concession covers approximately 40 square kilometres, producing 350 thousand ounces of gold in 2016 (Kim, van Moorsel, \& Kapstein, 2013; Newmont, 2017).

Newmont established the NADeF in 2008 to support community development programs in the Ahafo mine communities 5 in the Tano North and Asufiti North districts. The NADeF resulted from a two-year consultation process with the communities and other stakeholders, which first led to the formation of a fifty-four-member multi-stakeholder group, the Ahafo Social Responsibility Forum $(\mathrm{ASRF})^{6}$, and later to an agreement (Ahafo Social Responsibility Agreement) between the Ahafo mine communities and Newmont Ghana Gold Limited. Newmont contributes US\$ 1 per ounce of gold produced and $1 \%$ of the net pre-tax profit to the fund. In 2016, the NADeF spent approximately US\$ 2 million on development projects and had accrued US\$ 9 million as an endowment fund (NADeF, 2016).

The NADeF has a twelve-member secretariat and a board of trustees with nine board members. Whilst the secretariat serves as the main administrative body that designs, implements, and monitors the projects, it nevertheless answers to the board. Thus, the board has the responsibility and power to make the key decisions on investment and spending. The board includes the chairperson, who is nominated by the ASRF (must be approved by Newmont), two company representatives from Newmont, five community representatives nominated by the communities (non-ASRF members), and the head of the secretariat.

\footnotetext{
${ }^{5}$ Kenyasi No.1, Kenyasi No.2, Yamfo, Ntotroso, Wamahinso, Gyedu, Terchire, Adrobaa, Susuanso, and Afrisipakrom.

${ }^{6}$ The ASRF is composed of representatives from the ten Ahafo mine communities, local and regional governments, and civil society groups.
} 
The NADeF works in consultation with ten seven-member sustainable development committees, with each representing one of the ten mining communities (Ahafo Social Responsibility Agreement, 2008). The committee is the main linkage between the NADeF and the mining communities, and is composed of a youth representative and a women's representative, two traditional leaders, a unit committee representative (a local governmental division under the district assembly), and a community member nominated by the traditional authority. The ten committees, according to the NADeF, are proof of institutionalized community participation and ensure that the trust fund operates in a transparent manner. In addition, the committees work in conjunction with the Asufiti North and Tano North district assemblies to ensure that the fund's projects align with the districts' development plans and strategic goals. Other committees, such as the financial and administrative committee, project committees, the tender board, and the tender opening and evaluation committees, are involved in running the specific operations of the fund.

The NADeF has funded the construction of classroom blocks, libraries, health centres, the renovation of the chiefs' palaces, scholarships for further education, and micro-credit schemes for (mostly) women to engage in self-employment projects (Essah \& Andrews, 2016).

\section{Results}

\subsection{Transparency}

For information disclosure to be effective and promote local residents' participation in trust fund management, it must cover the inputs that the fund is receiving, the outputs (i.e., the funded projects), and the processes that link the two. Furthermore, the information needs to be timely, accessible, relevant, and understandable to the residents.

The interviews revealed that local residents feel that they do not obtain proper information on how much funding the funds receive from the mining companies. Commenting on this, a female 
trader in Obuasi said 'we are never told how much the AGA gives the trust fund for constructing toilets and boreholes; we are just told when they are finished and they say these are donations from the company'. Some of the residents also have an impression that the mining companies make more profits than the amount that they pay to the funds entails. As a male shop owner in Ahafo explained: 'there is no way we can know what is happening in the foundation, as they conceal information about the money they get from Newmont'. Unconvinced that the amount of money that the NADeF says it obtains from Newmont matches what the foundation should be receiving, the respondent added: 'even if you go to the office and ask them to let you see the accounts, they will tell you it is confidential'. A further issue indicated by some of the interviewees was that although local residents perhaps could obtain information on how much the fund was receiving, they still 'have no proof of how much profits the company made' (male, NGO representative).

In principle, some of the information that the residents are requesting is available. For example, the NADeF's and Newmont's annual reports and webpages provide information on how much the NADeF has received from the company. The annual reports also include information on the board's activities throughout the previous year, a presentation of commissioned projects, an auditor report, a statement on the financial position, and information on the fund's cash flow (NADeF, 2016). In addition, the NADeF has a notice board outside its office presenting information similar to that on its webpages. Thus, some information is accessible to residents if they visit the secretariat's office. The Obuasi Fund, on the other hand, does not have a website of its own; instead, it uses various platforms, such as radio, public information address systems situated in the communities, and posters, to inform people about its operations. In addition, a representative for the fund's secretariat said that 'the representatives in the steering committee broadcast whatever we do'.

Reflecting on the available information, several local residents indicated dissatisfaction with the content of the information that they receive from the two funds. Amongst other things, 
community members seem to lack information on how the inputs are leading to the outputs, as indicated by an NGO worker: 'they can tell the communities what they have done, but the information about the processes of realizing the projects never finds its way out'. Several respondents stated that they did not know the criteria and processes behind choosing a particular contractor for construction projects. For instance, a mason stated that he is 'interested in getting contracts for constructing some of [the] projects, but [that] it is difficult to know how the decisions are made to give such contracts'.

Many of the interviewed local residents said that not only did they have little information about the fund and its functions but they also found it very difficult to obtain information on the funds even when they wanted to know more. Some said that when the trust funds were first established, there was more information but that after a certain period, they experienced less communication from the funds. In Obuasi, in the beginning, the local residents were hopeful that the trust fund could be an initiative that would bring change to the communities. The trust fund had regular meetings with them, but later on, these became increasingly infrequent; 'Now, we just see things happening, but we do not know how or why and have no one to give answers to [our] questions' (male, small-scale miner).

There is an apparent contrast between trust funds' commitment 'to be open to our stakeholders' (NADeF website) and some of the information that is publicly available and people's awareness of the information. This situation indicates that the information channels between the funds and local residents are not adequate. Although there are meetings with the communities, many residents feel that they are excluded from the key meetings and thus from making substantial contributions to the funds' management. Indeed, the meetings organized by the trust funds such as the annual general meetings often involve key stakeholders such as the mining companies, traditional authorities, district assembly representatives, and some NGO representatives but only a few common 
community members. As a result, according to some residents, less information reaches them, as the representatives rarely share information from the meetings with them. Addressing the failure of information flow, one respondent felt that the meetings should be open and transparent to everybody who wishes to attend, 'but there are no such things here, and we cannot say that we participate in any decisions made or know exactly what is happening' (male, teacher).

Another issue that most respondents indicated as a major hindrance for accessing relevant information was the format, which makes it difficult for them to understand the content. On the NADeF website, the information provided is primarily in English, and it is very technical, perhaps providing a platform for only the outside world to observe the fund's engagement in addressing various social issues. Pointing to this issue, one respondent explained: 'the information that the NADeF has on their website only shows the good part, but we know there are a lot of issues in running the foundation. People are not satisfied with the way they work' (male, shopkeeper).

On other occasions, some residents were not satisfied with the frequency with which they receive information and felt that there were too long delays in obtaining responses from the trust funds. As a male local community leader said: 'we only know that things are happening when we are asked to attend the commissioning of certain projects, but when we tell the trust fund our problem, it can take a long time before we get an answer'. Another respondent, formerly a women's representative in the ASRF, explained: 'the ways by which information is given to the communities is not good enough. In my community, our representative does not live here and does not come to visit very often, not even to tell us about how our requests are handled'. Without adequate information, one cannot expect local people to form and provide views on the operations of the trust funds, nor can the communities have a chance to discuss issues about the trust funds with their representatives, as they lack a basis to discuss them. 
Based on the interviews, the overall picture is that although the trust funds claim that information about their operations, performance, and outcomes is available, the disclosed information is not substantial enough for the residents and is hard to reach. The residents lack information about the funds' processes and procedures, and in general, the information is not timely enough to allow the real-time monitoring and evaluation of the trust funds.

\subsection{Representation}

For community representation to contribute to meaningful participation in trust fund management, there must be a willingness by local community members to become involved in fund management, and they must have the opportunity to do so either directly or through their representatives.

The respondents indicated that the funds' alienation from the community decreased their willingness to be involved in the fund management. The interviews revealed that choices regarding the selection of the location for the secretariat's office and the fund's name were partially to blame for this alienation. The secretariat of the Obuasi Fund, for example, is located in a former AGA staff house approximately fifteen meters from the company's sustainability department office. To many, the location underscored the close affiliation between the trust fund and the company, decreasing the communities' sense of ownership and motivation to be involved in the operations of the trust fund: 'people do not visit the trust fund's office because they think it belongs to AGA and has nothing to do with the communities' (female, teacher). The NADeF, on the other hand, has "Newmont" as part of its name, and the company's colours dominate the foundation's website and all the funded projects. This close association between the company and the fund makes local residents feel that the NADeF does not belong to them but to the company: 'Maybe if they called it the Ahafo community foundation, more people would be curious and even consider it theirs' (local NGO worker). 
Further accounts on the issue of representation pointed to the role of the traditional authorities. In Ghana, these figures are the core local leaders, as the chieftainship is recognized by the constitution and plays a major role in various social and political aspects, particularly concerning the acquisition, ownership, and distribution of land. Administering land where minerals are found gives an advantage to the chiefs, who often assume the role of negotiator with the mining companies and, consequently, the trust funds. Confirming the strong position of the chiefs, a representative for an NGO in Obuasi stated that 'the Adansi chief either decides to sit on the board or appoints another person to represent him'.

According to most of the interviewed local residents, the representation by the chiefs is problematic. By far, the most pressing issue was that the people did not feel that the chiefs should represent them: 'Even though the chiefs and politicians represent us, they never ask our opinion. They just go there and say what they want. The problem we have is that the chief's house is respected, and it is almost a crime to disagree with what they say' (female, local trader). In particular, the youth felt little access to the chiefs, as explained by a 21 -year-old male high school dropout: 'It is always difficult for us to give opinions on how we want the money to be distributed or what we need to be funded because the chiefs and the assembly man always decide for us'.

A further issue is that the respondents felt that the chiefs, supposedly representing the community, did not necessarily seek to advance the interests of community development through the trust funds but, rather, sought to exploit their own personal opportunities. 'We are represented by our chiefs in the committees, but the chiefs are often sub-contracted by the mining company and consider themselves before us' (a former ASRF representative). Consequently, some respondents indicated that when the representative positions are left in the hands of the chiefs and local politicians, it leads to mistrust: 'Already in this country, we have issues with corruption in the mining sector, and it always involve some traditional authorities and local politicians. We find 
it difficult to trust these people as our representatives' (female, teacher). In addition, some interviewees pointed out that this type of representation caused tenders to not be awarded to ordinary community members: 'There are many people from our communities who can do these jobs, but because Newmont is always deciding for the NADeF, they only employ outsiders. I cannot get a contract to construct a toilet or classroom; mostly known business people and influential chiefs and politicians get these contracts' (male, entrepreneur).

Although, for example, NADeF's annual reports state that the Ahafo mining communities are represented in the ASRF through their chiefs, district assembly members, local NGOs, and other community members (NADeF, 2018), it was unclear to many respondents who their official representative in the fund was: 'If you go to the NADeF and complain, they will tell you to go and talk to your local representative. The problem is that most of us do not know who represents us in there. People sometimes say it is the chief, some say the assembly man, nothing is clear' (male, welder). Even when people knew whom they could contact to express their needs and concerns, many noted that it was difficult to gain audience to the representatives. Adding his opinion on representation, a small-scale miner in Obuasi described the situation by saying: 'There is no one amongst us with them'.

Overall, there was limited enthusiasm amongst the common citizens to engage in trust fund management, as they felt that the funds belonged to the companies rather than to the people and that the existing representation mechanisms restricted communities from directly deciding who should represent them in the trust funds and voice their concerns. To an extent, the results also provide evidence that the funds were strengthening the existing power relations and the social and political patronage networks already in place.

\subsection{Influence}


According to the trust fund representatives, the existence of the various committees provides spaces for community members to influence decisions. A representative for the NADeF said that the fund seeks to involve local communities in decision-making 'through a deliberative communication platform that brings to the table the voices of the public'. Similarly, the Obuasi Fund secretariat stressed that the engagement of community representatives in the steering committee was to strengthen their influence in decision-making.

The community members, however, almost unequivocally stated that the ways in which they are involved in the management of the funds does not contribute to having a real influence on the trust funds' operations. In fact, the overwhelming majority of the interviewees stated that they did not feel that the trust funds paid attention to their needs and concerns, even after they had voiced them. Even if one went to the secretariat, it was unlikely that the person would feel welcome and heard: 'You have to be a big man! You must be a chief, his associate, or a politician for them to listen to you' (an NGO representative). The fact that the community members felt that their wishes were not considered generated a feeling of a lack of substantial influence amongst the interviewees: 'However, even when we say these things, people who have more power are listened to more than us' (male, taxi driver).

Further, some residents felt that the existing committees are just ways to legitimize the functioning of the trust fund, given that the small committees have no influence and, ultimately, the board must approve all community need assessments and make the decisions. Moreover, the interviewees feel that even the committee members did not necessarily represent the local residents: 'These people who are in the committees do not really talk to the communities about the extent to which they can influence decisions. They go to the meetings, discuss amongst themselves, and decide what to do; very little of what they talk about is from the community members' (female, teacher). 
In conclusion, it emerges that even the interviewees who had a sense of responsibility and formal opportunity to influence the fund's decisions found the opportunities to have meaningful influence to be very limited. As a representative from a local NGO in Kenyasi 1 stated: 'We are considered to be stakeholders in NADeF but our opinions never form a strong part of the decisions made'. Similarly, their counterpart in Obuasi added: 'Our role in the trust fund can be questioned when it comes to decision-making, as our views rarely have a substantial impact'.

\section{Discussion and concluding remarks}

Proponents of transparency emphasize the role of information disclosure as a key to forming a basis for participation and catalysing citizen engagement to demand better management and increased accountability in the management of natural resources and their revenues (Epremian et al., 2016; Haufler, 2010). This article finds that the two case funds disseminate information to beneficiaries through different channels and seek to include community members through representatives in the fund boards and committees. Thus, at least some mechanisms that could contribute to transformative transparency and meaningful participation by local residents in the management of the funds are in place.

However, the results show that the disclosed information does not seem to reach the local residents, a finding that is in line with previous studies conducted on national-level information dissemination on natural resource management in Ghana (Lujala, Brunnschweiler, \& Edjekumhene, 2018; Ofori \& Lujala, 2015). The interviews also revealed that the current forms and the content of information from the two trust funds were not sufficient to form a transformative basis for the management of the funds. Taken together, there seems to be a clear gap between the community members and trust fund officials' perceptions of what constitutes transparency, where the latter see the mere information disclosure to be sufficient. 
Moreover, this study found that people actively tried to obtain information about the trust funds to only a limited degree. This finding can be due to several factors; for example, people have other pressing needs to attend to, or the information is of little value (Fox, 2015; Kosack \& Fung, 2014; Lieberman, Posner, \& Tsai, 2014; Lujala \& Epremian, 2017; Ofori \& Lujala, 2015). However, a crucial aspect for the people in the study areas was the feeling that they would not have had a real opportunity to influence fund management even if they had had the information and wanted to do so. This result suggests that people are rational in their information seeking: little effort is used to ends that are unlikely to improve their situation. Another frequently mentioned reason for limited interest towards the funds was their perceived dependence on the mining companies; the residents would like the funds to be more firmly in the hands of the local communities in order to reduce the influence of the mining company in the trust fund decision-making.

Further, the local residents felt that their representatives in the funds did not actually represent them. The fieldwork documented that most individuals representing communities had taken their roles by virtue of their social and political positions. According to the community members, this type of representation has led to decision-making that they cannot influence and to the implementation of projects that often do not address their pressing needs. ${ }^{7}$ Consequently, the role of the traditional authorities and assembly members as representatives for the local residents seemed to reinforce the existing forms of local power dynamics and to limit the local residents'

\footnotetext{
${ }^{7}$ Our meaning is not to imply that 'common people' would necessary always make better decisions than the 'elite', nor that 'elites' consider their own private interests first and foremost. Neither do we deny that common people can also be as captured by private interests as the elites (in fact, they are very likely to be). Our argument is that meaningful participation should allow community members to voice their opinions and concerns, and enable them to influence decisions that directly concern them (in this particular case, as the intended beneficiaries of the trust funds).
} 
influence on trust fund management, an outcome that has been documented in other cases of local decision-making (Cornwall, 2003; Dupuy, 2017; Maconachie, 2012).

In multi-stakeholder institutions, as in the trust funds studied, the strength of social and political affiliations and the positions of individuals affect resource management practices and the sharing of information and benefits. Thus, the existing social relations embedded within the local power dynamics can restrict spaces for local residents to influence decision-making and resource management. Therefore, there is a need to understand the micro politics of participation as a situated practice framed by local political, social, and cultural particularities.

The results presented in this article are disappointing considering that both trust funds make information available and actively seek to promote participation by local residents through various avenues. To enhance meaningful participation in the studied funds and other similar trust funds, the results from this article suggest that their governance structures - and profiles - should be as independent as possible from the mining companies and should be placed more in the hands of the communities that they are intended to benefit. In this regard, symbolic measures may also be important. In the case of the studied trust funds, there were requests to rename the NADeF to the Ahafo Community Development Foundation (i.e., to remove the company name from the fund's name) and relocate the Obuasi Fund's secretariat away from the company's premises to reduce the apparent relation between the fund and the company. The mechanisms to increase local residents' sense of ownership are central for the success of involving local people in the trust fund's management, and there needs to be a clear strategy for how to motivate local residents to take part in LBSTF management. Further, the trust funds should aim at disclosing information that is relevant, timely, and understandable for the local community members in such ways that it reaches the intended audience. Finally, community representatives in the trust funds should include not only those who already have social and political positions in the community but also individuals 
whom the beneficiaries themselves choose or elect for the purpose of the trust fund. Care should be exercised so that fund management does not simply mirror the existing social and political hierarchies. 


\section{References}

Ahafo Social Responsibility Agreement. (2008). Ahafo social responsibility agreement between the Ahafo mine local community and Newmont Ghana Gold Limited. Retrieved from http://ccsi.columbia.edu/files/2016/11/Ghana-Ahafo-Mine-Local-CommunityNewmont-Ghana-Gold-Ltd-2008-Social-Responsibility-Agreement.pdf

Akabzaa, T. M. (2009). Mining in Ghana: Implications for national economic development and poverty reduction. In B. Campbell (Ed.), Mining in Africa: Regulation and development (pp. 25-65). New York: Pluto Press.

Akabzaa, T. M., Seyire, J., \& Afriyie, K. (2007). The glittering facade: Effects of mining activities on Obuasi and its surrounding communities. Accra: Third World Network-Africa.

Andrews, N. (2016). Challenges of corporate social responsibility (CSR) in domestic settings: An exploration of mining regulation vis-à-vis CSR in Ghana. Resources Policy, 47(March), 9-17. doi:10.1016/j.resourpol.2015.11.001

Arellano-Yanguas, J. (2011). Aggravating the resource curse: Decentralisation, mining and conflict in Peru. The Journal of Development Studies, 47(4), 617-638.

Asuah, A. Y., \& Ankoye, P. A. (2016). The resilience of mining communities in Obuasi, as Anglogold Ashanti shifts position. Journal of Poverty, Investment and Development, $22,80-90$.

Ayensu, F. (2013). Managing Ghana's oil revenues: Ghana Petroleum Funds. Asian Journal of Humanities and Social Sciences, 1(2), 148-161.

Bebbington, A., Leni, D., Erwin, F., \& Scott, G. (2006). Local capacity, village governance, and the political economy of rural development in Indonesia. World Development, 34(11), 1958-1976. doi:10.1016/j.worlddev.2005.11.025 
Bloch, R., \& Owusu, G. (2012). Linkages in Ghana's gold mining industry: Challenging the enclave thesis. Resources Policy, 37(4), 434-442.

Campbell, I. C. (2011). Science, governance and environmental impacts of mines in developing countries: Lessons from Ok Tedi in Papua New Guinea. In R. Q. Grafton \& K. Hussey (Eds.), Water Resources Planning and Management (pp. 583-598). Cambridge: Cambridge University Press.

Cornwall, A. (2003). Whose voices? Whose choices? Reflections on gender and participatory development. World Development, 31(8), 1325-1342. doi:doi.org/10.1016/S0305750X(03)00086-X

Cornwall, A. (2006). Historical perspectives on participation in development. Commonwealth \& Comparative Politics, 44(1), 62-83. doi:10.1080/14662040600624460

Dupuy, K. E. (2017). Corruption and elite capture of mining community development funds in Ghana and Sierra Leone. In A. Williams \& P. Le Billion (Eds.), Corruption, natural resources and development: From resource curse to political ecology (pp. 69-79). Cheltenham, UK: Edward Elgar.

Elbra, A. (2017). A history of gold mining in South Africa, Ghana and Tanzania. In Governing African gold mining: Private governance and the resource curse (pp. 67-103). London: Palgrave Macmillan UK.

Epremian, L., Lujala, P., \& Bruch, C. (2016). High-value natural resources and transparency: Accounting for revenues and governance. Oxford Research Encyclopedia of Politics. doi:10.1093/acrefore/9780190228637.013.21.

Essah, M., \& Andrews, N. (2016). Linking or de-linking sustainable mining practices and corporate social responsibility? Insights from Ghana. Resources Policy, 50(December), 75-85. doi:10.1016/j.resourpol.2016.08.008 
Eversole, R. (2010). Remaking participation: challenges for community development practice. Community Development Journal, 47(1), 29-41.

Fabricius, C. (2013). The fundamentals of community-based natural resource management. In Rights Resources and Rural Development (pp. 18-58): Routledge.

Fox, J. (2015). Social accountability: What does the evidence really say? World Development, 72(August), 346-361. doi:10.1016/j.worlddev.2015.03.011

Gebara, M. F. (2013). Importance of local participation in achieving equity in benefit-sharing mechanisms for REDD+: a case study from the Juma Sustainable Development Reserve. International Journal of the Commons, 7(2), 473-497.

Gilberthorpe, E. (2013). Community development in Ok Tedi, Papua New Guinea: The role of anthropology in the extractive industries. Community Development Journal, 48(3), 466-483. doi:10.1093/cdj/bst028

Gilberthorpe, E., \& Papyrakis, E. (2015). The extractive industries and development: The resource curse at the micro, meso and macro levels. The Extractive Industries and Society, 2(2), 381-390. doi:10.1016/j.exis.2015.02.008

Haufler, V. (2010). Disclosure as governance: The Extractive Industries Transparency Initiative and resource management in the developing world. Global Environmental Politics, 10(3), 53-73. doi:10.1162/GLEP_a_00014

Heald, D. (2006). Varieties of transparency. In C. Hood \& D. Heald (Eds.), Transparency: The Key to Better Governance (pp. 25-43). Oxford: Oxford University Press

Hilson, G. (2012). Corporate Social Responsibility in the extractive industries: Experiences from developing countries. Resources Policy, 37(2), 131-137. 
IFC. (2015). The Art and Science of Benefit Sharing in the Natural Resource Sector. Retrieved from Washington, D.C.: http://commdev.org/wp-content/uploads/2015/07/IFC-Artand-Science-of-Benefits-Sharing-Final.pdf

Kim, R., van Moorsel, T., \& Kapstein, E. B. (2013). The national and regional socio-economic impact of Newmont Ghana's Ahafo mine. Retrieved from Steward Redqueen: http://www.stewardredqueen.com/uploads/publicaties/newmont_ghana_ahafo_mine socio_economic_impact_study_report_v001_b14e5m.pdf

Kolk, A. (2016). The social responsibility of international business: From ethics and the environment to CSR and sustainable development. Journal of World Business, 51(1), 23-34. doi:10.1016/j.jwb.2015.08.010

Kosack, S., \& Fung, A. (2014). Does transparency improve governance? Annual Review of Political Science, 17, 65-87.

Lawer, E. T., Lukas, M. C., \& Jørgensen, S. H. (2017). The neglected role of local institutions in the 'resource curse' debate. Limestone mining in the Krobo region of Ghana. Resources Policy, 54(December), 43-52. doi:10.1016/j.resourpol.2017.08.005

Lieberman, E. S., Posner, D. N., \& Tsai, L. L. (2014). Does Information Lead to More Active Citizenship? Evidence from an Education Intervention in Rural Kenya. World Development, 60, 69-83.

Lujala, P., Brunnschweiler, C., \& Edjekumhene, I. (2018). Transparent for whom? Dissemination of information on Ghana's petroleum and mining revenue management. Working Paper. Munich Personal RePEc Archive, Paper 84788.

Lujala, P., \& Epremian, L. (2017). Transparency and natural resource revenue management: Empowering the public with information? In A. Williams \& P. Le Billon (Eds.), 
Corruption, natural resources and development (pp. 58-68). Cheltenham, UK: Edward Elgar Publishing.

Maconachie, R. (2012). The Diamond Area Community Development Fund: Micropolitics and community-led development in post-war Sierra Leone. In P. Lujala \& S. A. Rustad (Eds.), High-value natural resources and post-conflict peacebuilding (pp. 261-273). New York: Routledge.

NADeF. (2016). 2015 Annual Report. Retrieved from http://www.nadef.org/downloads/2/22264.pdf

NADeF. (2018). 2017 Annual Report. Retrieved from file://C:/Users/paivil/Downloads/2017Annual-Report-1.pdf

Newmont. (2017). 2016 Annual Report. Retrieved from http://s1.q4cdn.com/259923520/files/doc_financials/annual/2016/Newmont-2016Annual-Report-Bookmarked-PDF-for-website.pdf

O'Faircheallaigh, C. (2010). Public participation and environmental impact assessment: Purposes, implications, and lessons for public policy making. Environmental impact assessment review, 30(1), 19-27.

O'Faircheallaigh, C. (2013). Extractive industries and Indigenous peoples: A changing dynamic? Journal of Rural Studies, 30 (April), 20-30. doi:10.1016/j.jrurstud.2012.11.003

O'Faircheallaigh, C., \& Corbett, T. (2005). Indigenous participation in environmental management of mining projects: The role of negotiated agreements. Environmental Politics, 14(5), $629-647$.

Ofori, J. J. Y., \& Lujala, P. (2015). Illusionary transparency? Oil revenues, information disclosure, and transparency. Society \& Natural Resources, 28(11), 1187-1202. doi:10.1080/08941920.2015.1024806 
OTDF. (2018). Annual Report 2017: Delivering with Innovation. Retrieved from https://www.otdfpng.org/wp-content/uploads/2018/05/OTDF-AR-2017-web-2.pdf

Ovadia, J. S. (2016). Local content policies and petro-development in Sub-Saharan Africa: A comparative analysis. Resources Policy, 49(September), 20-30. doi:10.1016/j.resourpol.2016.04.003

Perreault, T. (2015). Performing participation: Mining, power, and the limits of public consultation in Bolivia. The Journal of Latin American and Caribbean Anthropology, 20(3), 433451.

Ross, M., Lujala, P., \& Rustad, S. A. (2012). Horizontal inequality, decentralizing the distribution of natural resource revenues, and peace. In P. Lujala \& S. A. Rustad (Eds.), HighValue Natural Resources and Post-Conflict Peacebuilding (pp. 251-259). New York: Routledge.

Songi, O. (2015). Defining a path for benefit sharing arrangements for local communities in resource development in Nigeria: The foundations, trusts and funds (FTFs) model. Journal of Energy \& Natural Resources Law, 33(2), 147-170. doi:10.1080/02646811.2015.1022428

Speer, J. (2012). Participatory governance reform: A good strategy for increasing government responsiveness and improving public services? World Development, 40(12), 23792398. doi:10.1016/j.worlddev.2012.05.034

Standing, A. (2014). Ghana' s extractive industries and community benefit sharing: The case for cash transfers. Resources Policy, 40(June), 74-82. doi:10.1016/j.resourpol.2014.03.003

Wall, E., \& Pelon, R. (2010). Mining Foundations, Trusts and Funds, A Sourcebook. Retrieved from 
http://siteresources.worldbank.org/EXTOGMC/Resources/Sourcebook_Full_Report .$\underline{\mathrm{pdf}}$

Wall, E., \& Pelon, R. (2011) Sharing Mining Benefits in Developing Countries. In, Extractive Industries for Development Series 21. The Experience with Foundations, Trusts, and Funds. Washington DC: World Bank. 